\title{
Energy and mass balance of Zhadang glacier surface, central Tibetan Plateau
}

\author{
Guoshuai ZHANG, ${ }^{1}$ Shichang KANG, ${ }^{1,2^{*}}$ Koji FUJITA, ${ }^{3}$ Eva HUINTJES, ${ }^{4}$ Jianqing $X U,{ }^{5}$ \\ Takeshi YAMAZAKI ${ }^{6}$ Shigenori HAGINOYA, ${ }^{7}$ Yang WEI, ${ }^{1}$ Dieter SCHERER, ${ }^{8}$ \\ Christoph SCHNEIDER, ${ }^{4}$ Tandong YAO ${ }^{1,2}$
}

\author{
${ }^{1}$ Key Laboratory of Tibetan Environmental Changes and Land Surface Processes, Chinese Academy of Sciences, Beijing, China \\ E-mail: shichang.kang@itpcas.ac.cn \\ ${ }^{2}$ State Key Laboratory of Cryospheric Sciences, Chinese Academy of Sciences, Lanzhou, China \\ ${ }^{3}$ Graduate School of Environmental Studies, Nagoya University, Nagoya, Japan \\ ${ }^{4}$ Department of Geography, RWTH Aachen University, Aachen, Germany \\ ${ }^{5}$ Japan Agency for Marine-Earth Science and Technology, Yokohama, Japan \\ ${ }^{6}$ Department of Geophysics, Graduate School of Science, Tohoku University, Sendai, Japan \\ ${ }^{7}$ Meteorological Research Institute, Tsukuba, Japan \\ ${ }^{8}$ Department of Ecology, Technical University of Berlin, Berlin, Germany
}

\begin{abstract}
Climate variables that control the annual cycle of the surface energy and mass balance on Zhadang glacier in the central Tibetan Plateau were examined over a 2 year period using a physically based energy-balance model forced by routine meteorological data. The modelled results agree with measured values of albedo, incoming longwave radiation, surface temperature and surface level of the glacier. For the whole observation period, the radiation component dominated $(82 \%)$ the total surface energy heat fluxes. This was followed by turbulent sensible $(10 \%)$ and latent heat $(6 \%)$ fluxes. Subsurface heat flux represented a very minor proportion $(2 \%)$ of the total heat flux. The sensitivity of specific mass balance was examined by perturbations of temperature $( \pm 1 \mathrm{~K})$, relative humidity $( \pm 20 \%)$ and precipitation $( \pm 20 \%)$. The results indicate that the specific mass balance is more sensitive to changes in precipitation than to other variables. The main seasonal variations in the energy balance were in the two radiation components (net shortwave radiation and net longwave radiation) and these controlled whether surface melting occurred. A dramatic difference in summer mass balance between 2010 and 2011 indicates that the glacier surface mass balance was closely related to precipitation seasonality and form (proportion of snowfall and rainfall).
\end{abstract}

\section{INTRODUCTION}

Against the background of global warming, the variations of glaciers in the Tibetan Plateau (TP) area and their effect on the surrounding environment have drawn great attention (Immerzeel and others, 2010; Bolch and others, 2012). Accompanied by a significant temperature increase since the mid-19th century, the majority of glaciers on the TP have retreated (e.g. Yao and others, 2004; Sakai and others, 2006; Ye and others, 2006). Numerical studies have shown that glaciers in the TP have retreated with increasingly negative mass balance in recent years (e.g. Shi and Liu, 2000; Xiao and others, 2007; Li and others, 2008; Bolch and others, 2010). Glacial retreat and significant mass loss may not only cause natural hazards such as landslides and glacier lake outburst floods but also endanger water resources in the longer term (Immerzeel and others, 2010).

Investigations of the relationship between climate and glacier mass balance have been undertaken using various empirical and physical models (e.g. Andreas, 1987; Braithwaite and Olesen, 1990; Kayastha and others, 1999; Hock, 2005). Physical models provide direct estimates of energy-balance components, but detailed observational data are required for validation. Owing to the lack of observational data for the TP, few studies have applied physical

*Present address: Institute of Tibetan Plateau Research, Chinese Academy of Sciences, Beijing, China. models to investigate glacier surface energy and mass balance in the region. Observations of climate and mass balance for Zhadang glacier in the central TP have been conducted since 2005 (Kang and others, 2009; Zhou and others, 2010), providing an opportunity to test an energybalance model for glacier energy and mass balance. Formulating a realistic physically based model of glacier mass balance is critical to predicting future glacier change under different climate projections, especially given that very few such studies have been undertaken in the TP (Takahashi and others, 1989; Zhang and others, 1996; Yang and others, 2011).

\section{FIELD OBSERVATIONS}

Zhadang glacier (Fig. 1) is on the northeastern slope of Nyainqentanglha mountain in the central TP $\left(30^{\circ} 28.57^{\prime} \mathrm{N}\right.$, $90^{\circ} 38.71^{\prime} \mathrm{E}$; area $2.0 \mathrm{~km}^{2}$; length $2.2 \mathrm{~km}$ ). This valley-type glacier faces north-northwest and flows from 6090 to $5515 \mathrm{~m}$ a.s.l. It is debris-free and has a fan-shaped terminus (Chen and others, 2009). Two automatic weather stations (AWSs) have been operating at Zhadang glacier since May 2005 (AWS1 at $5400 \mathrm{ma.s.l}$. and AWS3 at $5800 \mathrm{ma.s.l.;}$ Fig. 1). An automatic energy-budget station which provides the data for analysis located in the ablation zone has been operational since May 2009 (AWS2 at 5660 ma.s.I.; Maussion and others, 2011). AWS2 measures the following 

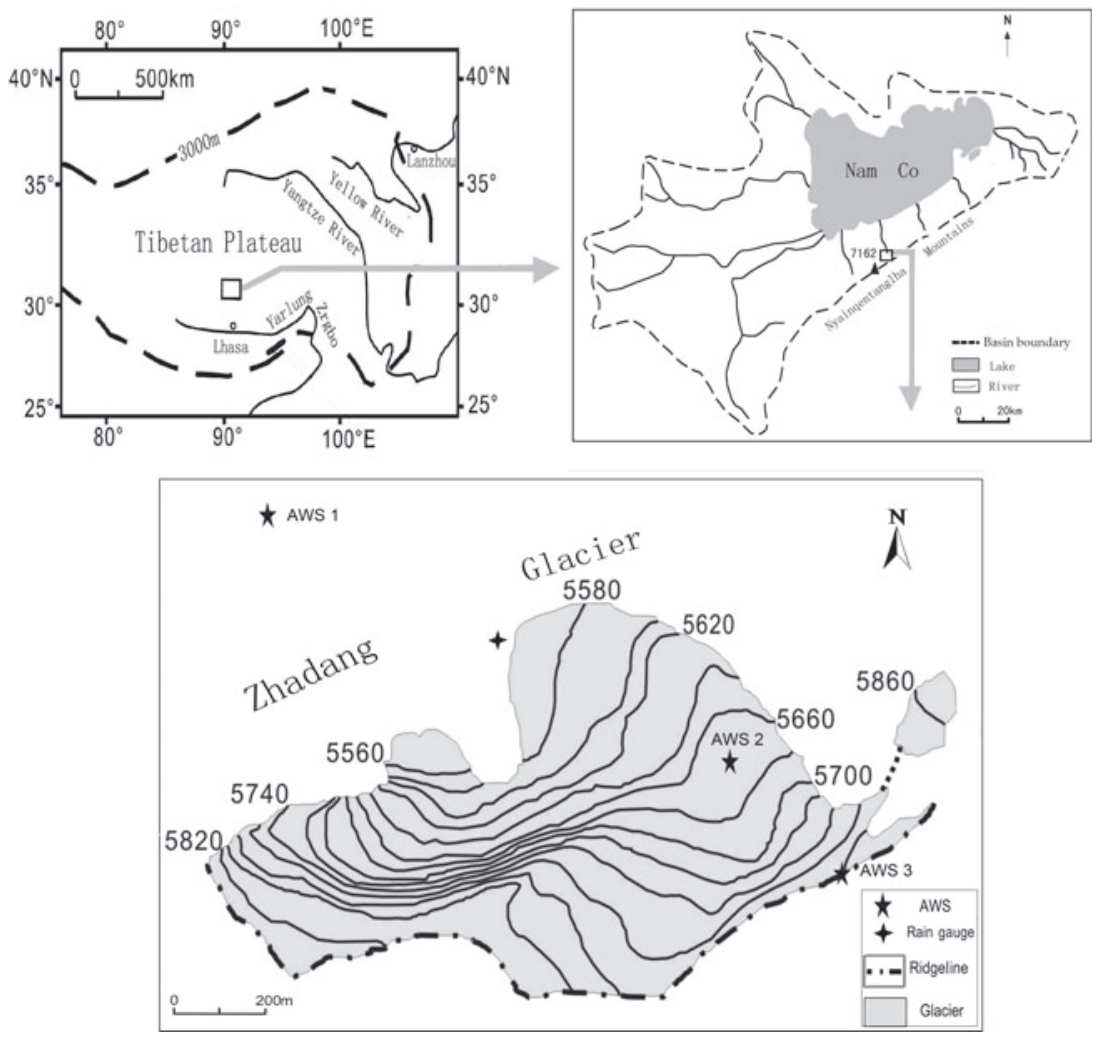

Fig. 1. Location of Zhadang glacier and the AWSs. Glacier contours are from a 1970 topographic map and the glacier outline is from a Landsat image recorded in 2007.

data every 10 min for a nearly horizontal glacier surface: incoming and reflected solar radiation, air temperature, relative humidity, air pressure, net radiation $(1.8 \mathrm{~m}$ above the glacier surface), wind speed and wind direction ( $2.5 \mathrm{~m}$ above the glacier surface) and surface temperature. Surface level of the glacier at AWS2 was measured by a sonic ranging sensor. At the glacier terminus (5580 ma.s.l.), an all-weather rain gauge with a hanging weighing transducer (T200b) has been operating since 21 May 2010 (Fig. 1). Details of the AWSs and rain gauge instruments are listed in Table 1.

Table 1. Overview of AWSs and rain gauge instruments and their specifications

\begin{tabular}{|c|c|c|}
\hline Sensor type & Parameter & Accuracy \\
\hline \multirow[t]{2}{*}{ Campbell CS215 } & Air temperature & $\begin{array}{c} \pm 0.4^{\circ} \mathrm{C}\left(5-40^{\circ} \mathrm{C}\right), \pm 0.9^{\circ} \mathrm{C} \\
\left(-40^{\circ} \mathrm{C} \text { to }+40^{\circ} \mathrm{C}\right)\end{array}$ \\
\hline & Relative humidity & $\begin{array}{c} \pm 2 \% \\
(10-90 \% \text { relative humidity) }\end{array}$ \\
\hline Young 05103 & $\begin{array}{l}\text { Wind speed } \\
\text { Wind direction }\end{array}$ & $\begin{array}{c} \pm 0.3 \mathrm{~m} \mathrm{~s}^{-1} \\
\pm 3^{\circ}\end{array}$ \\
\hline $\begin{array}{l}\text { T. Friedrichs and Co. } \\
\text { DPI740 }\end{array}$ & Air pressure & $\pm 400 \mathrm{~Pa}$ \\
\hline Campbell CS300 & $\begin{array}{l}\text { Solar radiation } \\
\text { (incoming and } \\
\text { reflected) }\end{array}$ & $\pm 5 \%$ for daily totals \\
\hline Apogee IRTS-P & Surface temperature & $\pm 0.3^{\circ} \mathrm{C}$ from $5^{\circ} \mathrm{C}$ to $45^{\circ} \mathrm{C}$ \\
\hline Campbell 107TP & Ice temperature & $\pm 0.9^{\circ} \mathrm{C}$ from $-35^{\circ} \mathrm{C}$ to $+50^{\circ} \mathrm{C}$ \\
\hline Campbell NR-Lite & $\begin{array}{l}\text { Net all-wave } \\
\text { radiation }\end{array}$ & $\begin{array}{c} \pm 5 \% \text { typical } \\
( \pm 10 \% \text { worst case })\end{array}$ \\
\hline Campbell SR50 & Surface height & $\pm 0.01 \mathrm{~m}$ \\
\hline Geonor T200B & Precipitation & $\pm 0.6 \mathrm{~mm}$ \\
\hline
\end{tabular}

The temperature and relative humidity sensors are in ventilated radiation shields (THIES Clima $\mathrm{GmbH}$ ). The ventilators are directly connected to two solar panels, which prevent temperature errors introduced by radiation overheating. Relative humidity measurements recorded when temperature was below $0^{\circ} \mathrm{C}$ and were corrected using the method of Curry and Webster (1999). To avoid the effect of a poor cosine response of the radiation sensors at low sun angles, and a possible phase shift due to tilting of the sensor during the daily cycle of incoming solar radiation (Giesen and others, 2009), the albedo $(\alpha)$, defined as the ratio of the reflected to the incident shortwave radiation, was calculated using the accumulated albedo method (Van den Broeke and others, 2004).

AWS2 toppled over on 1 July 2009 and rested horizontally on the ice surface until 12 August 2010. For this time interval, only surface height and air pressure data are available from this station. However, a near-linear relationship between the meteorological data of AWS1, AWS2 and an AWS at the Nam Co station (Fig. 1) allowed us to linearly interpolate temperature, relative humidity, wind speed and global radiation for this data gap using data from AWS1 and the Nam Co AWS. Sonic ranging sensor connectivity problems resulted in two gaps in the surface height data in 2011 (22 March-20 April and 21 May-28 June).

Because of the gentle slope and small distance from the gauge site to AWS2, the topographic effects of precipitation were neglected. The data from the rain gauge were used directly as the precipitation amount for the AWS2 site. For the period before the rain gauge was operational, daily precipitation amounts were deduced from sonic ranging data with a snowpack density value of $400 \mathrm{~kg} \mathrm{~m}^{-3}$ (average observed values from snow pit) during the winter from 

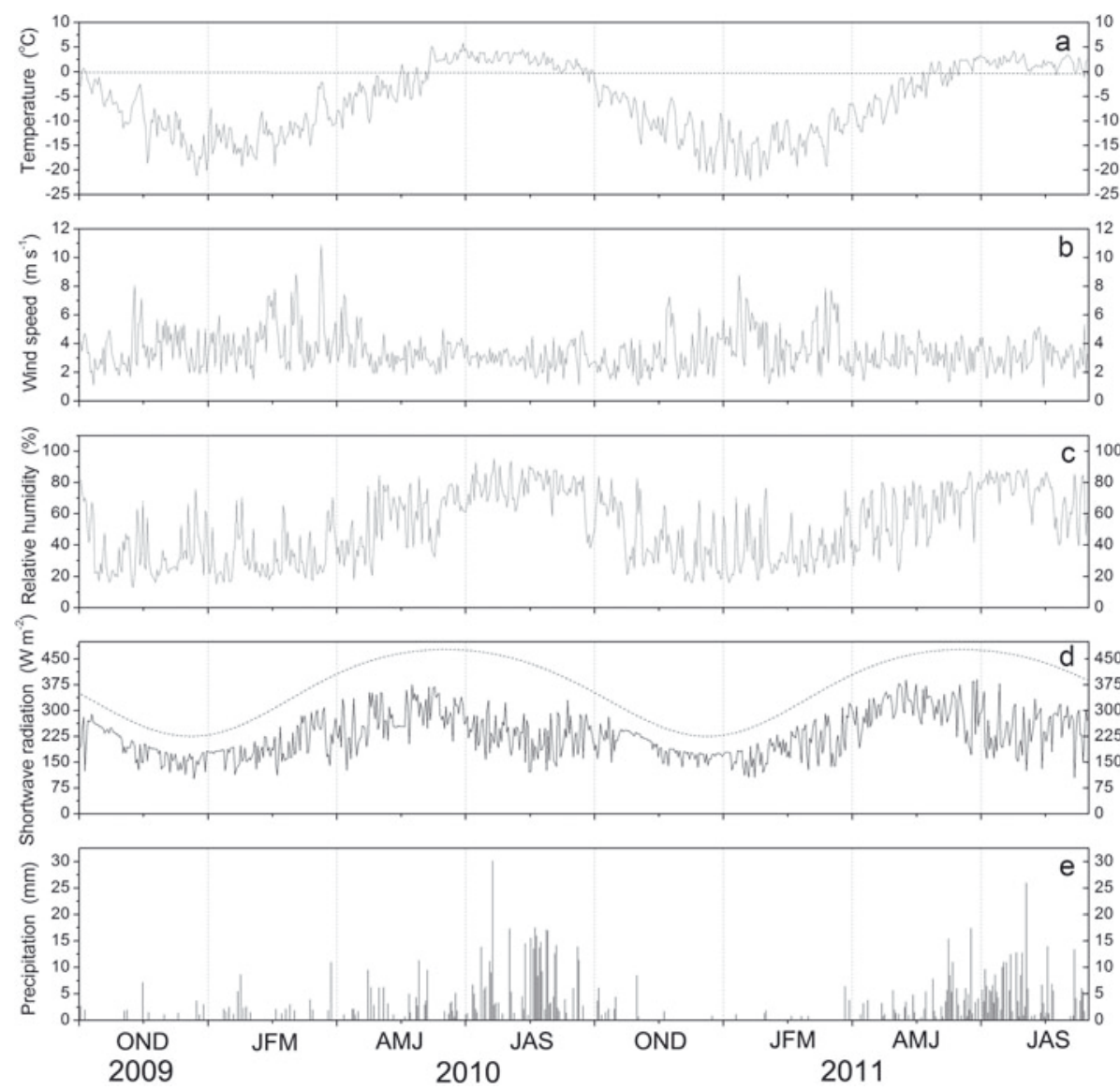

Fig. 2. Daily mean values of (a) air temperature, (b) wind speed, (c) relative humidity, (d) global solar radiation and (e) precipitation at Zhadang glacier during the study period from 4 October 2009 to 15 September 2011. Dashed line in (d) indicates calculated extraterrestrial solar irradiance. (OND = October to December, etc.)

4 October 2009 to 20 May 2010 and the densification process of snowpack was not considered here.

\section{CLIMATE CONDITIONS AT THE STUDY SITE}

The Nyainqentanglha mountain region is affected by both the Indian summer monsoon and westerlies during winter (Yatagai and Yasunari, 1998), producing distinct seasonal oscillation of the climate. Summer is associated with intense solar heating and moisture transported by the Indian monsoon. In contrast, low sun elevation and strong westerlies cause cold dry windy winters. Figure 2 shows meteorological parameters for Zhadang glacier for the two mass-balance years that were used as the input data for the model. Daily mean temperature changed markedly with the seasons, with a range of $-22.1^{\circ} \mathrm{C}$ to $5.8^{\circ} \mathrm{C}$. From late May to September, daily temperatures generally rose above $0^{\circ} \mathrm{C}$ at the study site. Relative humidity and precipitation also showed seasonal variation. Because of the high atmospheric transmissivity on the TP, incoming solar radiation can reach $88 \%$ of the extraterrestrial solar radiation value. Wind also varied seasonally: in summer, the wind speed never exceeded $10 \mathrm{~m} \mathrm{~s}^{-1}$ and the wind direction was predominantly from the southeast; whereas in winter, wind was much stronger and came predominantly from the northwest (Fig. 3). From the observation at the Nam Co station, $>90 \%$ of the precipitation was delivered between May and September in 2005/06 (You and others, 2007). May to September is considered the wet season and the corresponding dry season is from October to April. The accumulation and ablation seasons of the glacier overlap in summer (Kang and others, 2009). Glaciers in this region are therefore defined as summer-accumulation-type glaciers (SAT glaciers) (Ageta and Higuchi, 1984), the mass balance of which is considered to be more sensitive to temperature change than that of winter-accumulation-type glaciers (Fujita, 2008).

\section{SURFACE ENERGY- AND MASS-BALANCE MODEL}

Energy balance at the glacier surface can be expressed as

$$
S_{\text {in }}+S_{\text {out }}+L_{\text {in }}+L_{\text {out }}+H_{\mathrm{S}}+H_{\mathrm{L}}+G-Q=0
$$

where $S_{\text {in }}$ is incoming shortwave or global radiation, $S_{\text {out }}$ is reflected shortwave radiation, $L_{\text {in }}$ is incoming longwave radiation, $L_{\text {out }}$ is outgoing longwave radiation, $H_{\mathrm{S}}$ is turbulent sensible heat flux, $H_{\mathrm{L}}$ is turbulent latent heat flux, $G$ is subsurface heat flux and $Q$ is heat flux for melting. Energy fluxes are defined as positive when directed toward the glacier surface and negative when directed away from the surface. Thus Eqn (1) can be expressed as

$$
S_{\text {net }}+L_{\text {net }}+H_{\mathrm{S}}+H_{\mathrm{L}}+G=Q
$$

where $S_{\text {net }}$ is net shortwave radiation $\left(S_{\text {net }}=S_{\text {in }} \times(1-\alpha)\right)$ and $L_{\text {net }}$ is net longwave radiation $\left(L_{\text {in }}+L_{\text {out }}\right)$.

Surface albedo $\left(\alpha=-S_{\text {out }} / S_{\text {in }}\right)$ is a critical factor in the mass balance of a glacier surface (Van de Wal and others, 1992). Considering their dramatically different effects on albedo, snow and ice surfaces are treated individually in this model. Although there are many methods to quantify snow 


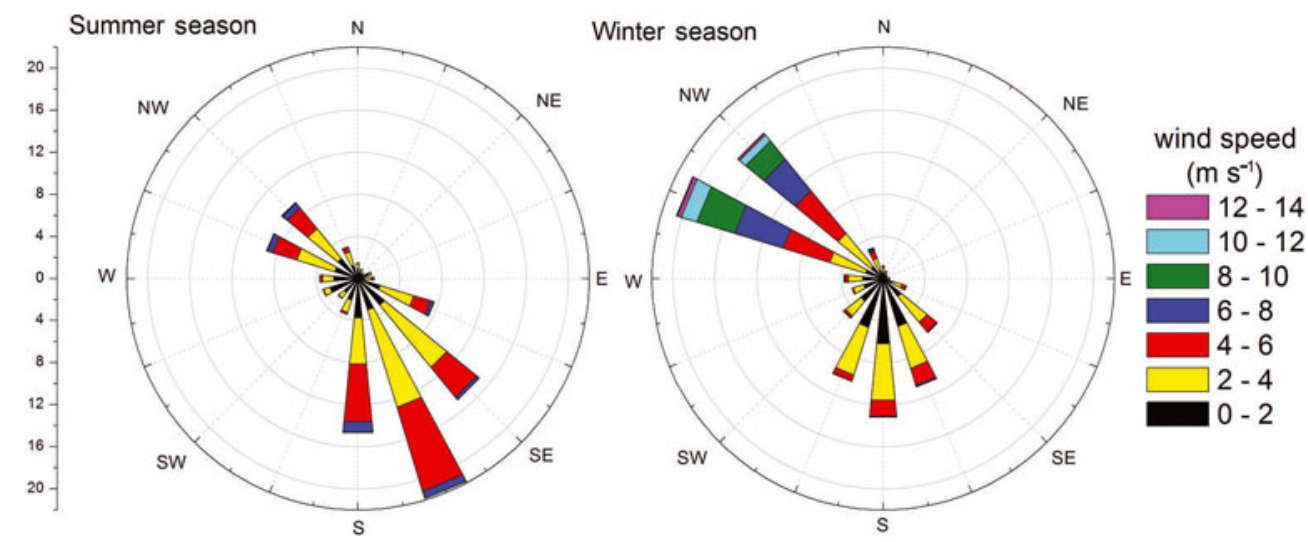

Fig. 3. Wind direction and intensity of half-hourly observational data at AWS2 for summer and winter (summer: 1 May-30 September 2010 and 1 May-15 September 2011; winter: 4 October 2009 to 30 April 2010 and 1 October 2010 to 30 April 2011).

albedo (Brock and others, 2000), most define albedo as a high constant value when significant snowfall occurs and a steadily decreasing value with time after snowfall (e.g. US Army Corps of Engineers, 1956; Oerlemans and Knap, 1998). The problem with this approach is that it yields large discrepancies between measured and modelled albedo during prolonged periods without snowfall (Hock and Holmgren, 2005).

The parameterization of snow-surface albedo in the model used in the present study followed the method of Yamazaki and others (1993), which evaluates surface albedo based on surface snow density, taking into account multiple reflections in the surface snow layer and assuming that each such layer consists of an ice plate and an air layer in the vertical dimension. This parameterization method also considered the influence of water and the progress of compactive viscosity as shown by Fujita and Ageta (2000). Ice-surface albedo was assumed to vary as a function of dew-point temperature (Mölg and others, 2008).

The contribution of incoming longwave radiation to energy balance was calculated using standard meteorological variables. A key point is the parameterization of atmospheric emissivity (Crawford and Duchon, 1999). Brutsaert (1975) developed a physically rigorous formula to express the relationship between atmospheric emissivity $(\varepsilon)$ and meteorological parameters as

$$
\varepsilon=(1-\text { clf })+\text { clf } \times 1.24 \times(e / T)^{1 / 7}
$$

where clf is the ratio of the measured incoming shortwave radiation to the incoming shortwave radiation at the top of the atmosphere, and $T$ and $e$ are the air temperature and vapour pressure, respectively. Sicart and others (2010) pointed out that the parameterization performed better for daily than for hourly simulations. Therefore, the average daytime clf was used to calculate daily $L_{\text {in }}$. Thus the amount of incoming longwave radiation can be expressed as

$$
L_{\text {in }}=\sigma \varepsilon T^{4}
$$

where $\sigma$ is the Stefan-Boltzmann constant.

$L_{\text {out }}$ was obtained by the Stefan-Boltzmann law from modelled surface temperature and surface emissivity (being set to 1).

Turbulent sensible $\left(H_{\mathrm{S}}\right)$ and latent heat fluxes $\left(H_{\mathrm{L}}\right)$ were calculated by the bulk aerodynamic method. The gradients of mean horizontal wind speed $(U)$, mean air temperature $(T)$ and mean specific humidity $(q)$ were assumed to be equal to the finite difference between the measurement level and the surface. The turbulent fluxes were expressed as

$$
\begin{gathered}
H_{\mathrm{S}}=\rho C_{P} \cup C_{\mathrm{S}}\left(T-T_{\mathrm{S}}\right) \\
H_{\mathrm{L}}=\rho l_{f} \cup C_{\mathrm{L}}\left(q-q_{\mathrm{s}}\right)
\end{gathered}
$$

where $\rho$ is air density, $C_{P}$ is the specific heat capacity of air, $T$ is air temperature, $T_{\mathrm{s}}$ is surface temperature, $q_{\mathrm{s}}$ is specific humidity at the surface, $U$ is wind speed, $I_{f}$ is latent heat of evaporation $\left(2.514 \times 10^{6} \mathrm{~J} \mathrm{~kg}^{-1}\right)$ or sublimation $(2.849 \times$ $\left.10^{6} \mathrm{~J} \mathrm{~kg}^{-1}\right)$, which are used based on surface temperature, and $C_{S}$ and $C_{\mathrm{L}}$ are the bulk exchange coefficients for sensible and latent heat, respectively. Constant bulk exchange coefficients $\left(C_{\mathrm{S}}=C_{\mathrm{L}}=0.002\right.$; Kondo and Yamazawa, 1986) were used to calculate the turbulent heat flux as recommended by Fujita and Ageta (2000) and Sakai and others (2009) because surface roughness and wind profiles are unknown over snow and ice in this case.

Total energy flux in the subsurface consists of the energy flux from penetrating shortwave radiation together with conductive heat flux. The former was calculated as an exponential decline of net shortwave radiation with increasing depth from the surface and it is assumed that the extinction coefficient is a constant value $\left(40 \mathrm{~m}^{-1}\right)$ for both snow and ice and independent of snow density, grain size, wavelength or other properties (Fukami and others, 1985). Fukami and others (1985) pointed out that the thermal influence of solar radiation occurs almost entirely above a depth of $0.1 \mathrm{~m}$ in the extinction coefficient range 20$100 \mathrm{~m}^{-1}$. The conductive heat flux in the subsurface was expressed according to the temperature profiles during a given time-span:

$$
\begin{aligned}
G & =K \frac{\partial T}{\partial t} \\
K_{\mathrm{s}} & =0.029\left(1+10^{-4} \rho_{s}^{2}\right) \\
K_{\mathrm{i}} & =\frac{488.2}{273.2+T_{Z}}+0.47
\end{aligned}
$$

where $K$ is thermal conductivity, of which different values are used for snow $\left(K_{\mathrm{s}}\right)$ and ice $\left(K_{\mathrm{i}}\right)$. In this model, $K_{\mathrm{s}}$ was calculated as a function of snow density following Mellor (1977), whereas $K_{\mathrm{i}}$ was obtained as a function of ice temperature (Hobbs, 1974).

Surface temperature $\left(T_{\mathrm{s}}\right)$ is a key variable for the glacier surface energy balance. It is calculated using an iterative procedure from the energy available at the surface (Andreas, 
1987; Fujita and Ageta, 2000; Fujita and others, 2007). If $T_{\mathrm{s}}$ exceeds the melting point, it is set to $273.15 \mathrm{~K}$ and the remaining flux represents the heat flux for melting $(Q)$.

Refreezing water in the subsurface was also considered. Refreezing may take place in a range of englacial and supraglacial locations. Refreezing takes place in the snow layer when percolating early summer meltwater refreezes in the cold snow layer and in the capillary water stored in snow pore spaces at the end of summer (Braithwaite and others, 1994; Fujita and others, 1996; Schneider and Jansson, 2004). Because of the presence of cold ice below the snow layer, meltwater can also refreeze to form superimposed ice at the interface between snow and ice layers (Marsh and Woo, 1984; Pfeffer and Humphrey, 1996). It was assumed that the snow layer can retain $5 \%$ of its volume as water $\left(W_{\text {retain }}\right)$ (Fujita and Ageta, 2000). The amount of refrozen water (RW) was calculated from the temperature profile of snow and ice as follows:

$$
\begin{gathered}
\text { dry cold snow layer: } \mathrm{RW}=\frac{\rho_{\mathrm{s}} C_{\mathrm{i}}}{I_{f}} \int_{\text {surface }}^{\text {interface }} \Delta T_{\mathrm{i}} \mathrm{d} z \\
\text { wet snow layer: } \mathrm{RW}=\min \left\{\frac{\rho_{\mathrm{i}} C_{\mathrm{i}}}{l_{f}} \int_{\text {interface }}^{\mathrm{z}} \Delta T_{\mathrm{i}} \mathrm{d} z, W_{\text {retain }}\right\}
\end{gathered}
$$

$$
\text { interface of snow and ice layers: } \mathrm{RW}=\frac{\rho_{\mathrm{i}} C_{\mathrm{i}}}{l_{f}} \int_{\text {interface }}^{z} \Delta T_{\mathrm{i}} \mathrm{d} z
$$

where $C_{\mathrm{i}}$ is the specific heat of ice, $I_{f}$ is the latent heat of melting, $z$ is the depth where the energy fluxes become nil, and $\rho_{s}$ and $\rho_{i}$ are the density of snow and ice, respectively.

Precipitation at high altitudes occurs as solid (snowfall), liquid (rainfall) and mixed phases (Kayastha and others, 1999). The proportion of snowfall versus rain is governed by the wet-bulb temperature $T_{\mathrm{W}}$ (Yamazaki, 2001). The following equations are proposed for the fraction $([0,1])$ of snowfall $\left(P_{\mathrm{s}}\right)$ in the total precipitation $\left(P_{\mathrm{p}}\right)$ :

$$
\begin{array}{ll}
P_{\mathrm{S}}=1-0.5 \exp \left(-2.2\left(1.1-T_{\mathrm{W}}\right)^{1.3}\right) & T_{\mathrm{W}}<1.1^{\circ} \mathrm{C} \\
P_{\mathrm{S}}=0.5 \exp \left(-2.2\left(T_{\mathrm{W}}-1.1\right)^{1.3}\right) & T_{\mathrm{W}} \geq 1.1^{\circ} \mathrm{C}
\end{array}
$$

and the amount of rainfall is expressed as

$$
P_{\mathrm{r}}=P_{\mathrm{p}}\left(1-P_{\mathrm{s}}\right)
$$

Wet-bulb temperature, $T_{\mathrm{W}}$, can be calculated as

$$
T_{\mathrm{W}}=\frac{\left(B \times T_{\mathrm{a}}+e-6.086\right)}{(0.476+B)}
$$

$B=0.0006336 \times p$, where $T_{\mathrm{a}}$ is air temperature $\left({ }^{\circ} \mathrm{C}\right), e$ is water vapour pressure $(\mathrm{hPa})$ and $p$ is air pressure $(\mathrm{hPa})$.

\section{VALIDATION OF THE MODEL}

A set of observed daily data (air temperature, relative humidity, wind speed, incoming shortwave radiation and precipitation) from 4 October 2009 to 15 September 2011 was used as input data to run the energy-balance model. The snow thickness and average ice temperature recorded on 4 October 2009 were used as the initial conditions. Validation of the model results against the measured data was undertaken as described below.

Comparisons of observed and calculated variables for AWS2 (Fig. 4) indicate that the modelled surface albedo values are similar to the observed values (Fig. 4a). Since a constant value was used for snow density (mean values of the field observations: $400 \mathrm{~kg} \mathrm{~m}^{-3}$ ), the modelled albedo had almost the same value even after a significant snowfall, which caused a small discrepancy between the observed and modelled values. The observed albedo values were both lower than calculated in early June 2010 and early July 2011. This may be due to the deposition of dust in the beginning of the melt season (Fujita and Ageta, 2000; Fujita, 2007), which was not considered in the model. However, the results of the modelled snow surface albedo are generally acceptable. In this study, the ice albedo varied as a function of dew-point temperature, which strongly affects ice surface albedo (Mölg and others, 2008). Since observations of albedo data in summer 2010 are lacking, this method could only be validated through mass-balance results because observed changes of surface level during the period were affected by the data gap. Although $L_{\text {in }}$ was not measured directly by AWS2, it was calculated as a residual using data from three of the other four components of net radiation ( $L_{\text {out }}$ was calculated based on measured surface temperature). The results show a close correlation between the modelled and observed data (Fig. 4b). Figure 4c presents a comparison of observed and calculated surface temperatures. During the data gap in summer 2010, the daily mean air temperature was always above $0^{\circ} \mathrm{C}$, and thus the modelled daily surface temperature was $0^{\circ} \mathrm{C}$. Variations in snow depth and the amount of melting ice (which has a density of $900 \mathrm{~kg} \mathrm{~m}^{-3}$ ) were also validated by observed surface level data (Fig. 4d). The modelled results agree well with the observed values, thereby confirming the low value for ice-surface albedo during the data gap in summer 2010. In general, the model incorporated almost all the energy exchange that took place at the glacier surface and performed well in calculating these variables.

\section{RESULTS}

\section{Energy balance}

Daily surface energy components of the energy balance are shown in Figure 5. The energy-balance results indicate that $S_{\text {net }}$ was highly variable, from a very high average value of $92 \mathrm{~W} \mathrm{~m}^{-2}$ in summer to a low of $46 \mathrm{~W} \mathrm{~m}^{-2}$ in winter (Table 2). Aside from seasonal changes in sun elevation, the main reason for the seasonal variability of $S_{\text {net }}$ is the varying glacier surface albedo. The average albedo (0.8) indicates that the snow surface reflected most of $S_{\text {in }}$ during winter. In contrast, the lower average albedo (0.65) during summer was associated with surface melt. The mean value of $L_{\text {net }}$ in summer was $-47 \mathrm{~W} \mathrm{~m}^{-2}$, slightly less than the mean value of $-59 \mathrm{~W} \mathrm{~m}^{-2}$ in winter. This difference is related to variations in $L_{\text {in }}$ and $L_{\text {out }}$, the two components of $L_{\text {net }}$. The value of $L_{\text {out}}$, which is governed by glacier surface temperature, exhibited regular seasonal changes during the 2 years of observations. The value of $L_{\mathrm{in}}$, depending on atmospheric temperature, cloud cover and humidity, was high in summer and low in winter (Table 3; Fig. 4). Positive $H_{S}$ indicates heat transfers from the air to the glacier surface throughout the year. The seasonal variation in $H_{S}$ points to a larger temperature gradient in winter than in summer (Table 3). For turbulent $H_{\mathrm{L}}$, a sign shift from negative to positive occurred during summer. The relatively high air temperature and relative humidity (Table 3 ) leads to a reversal of the humidity gradient and therefore a positive $H_{\mathrm{L}}$ for a melting valley glacier (Oerlemans, 2000). The windy conditions 

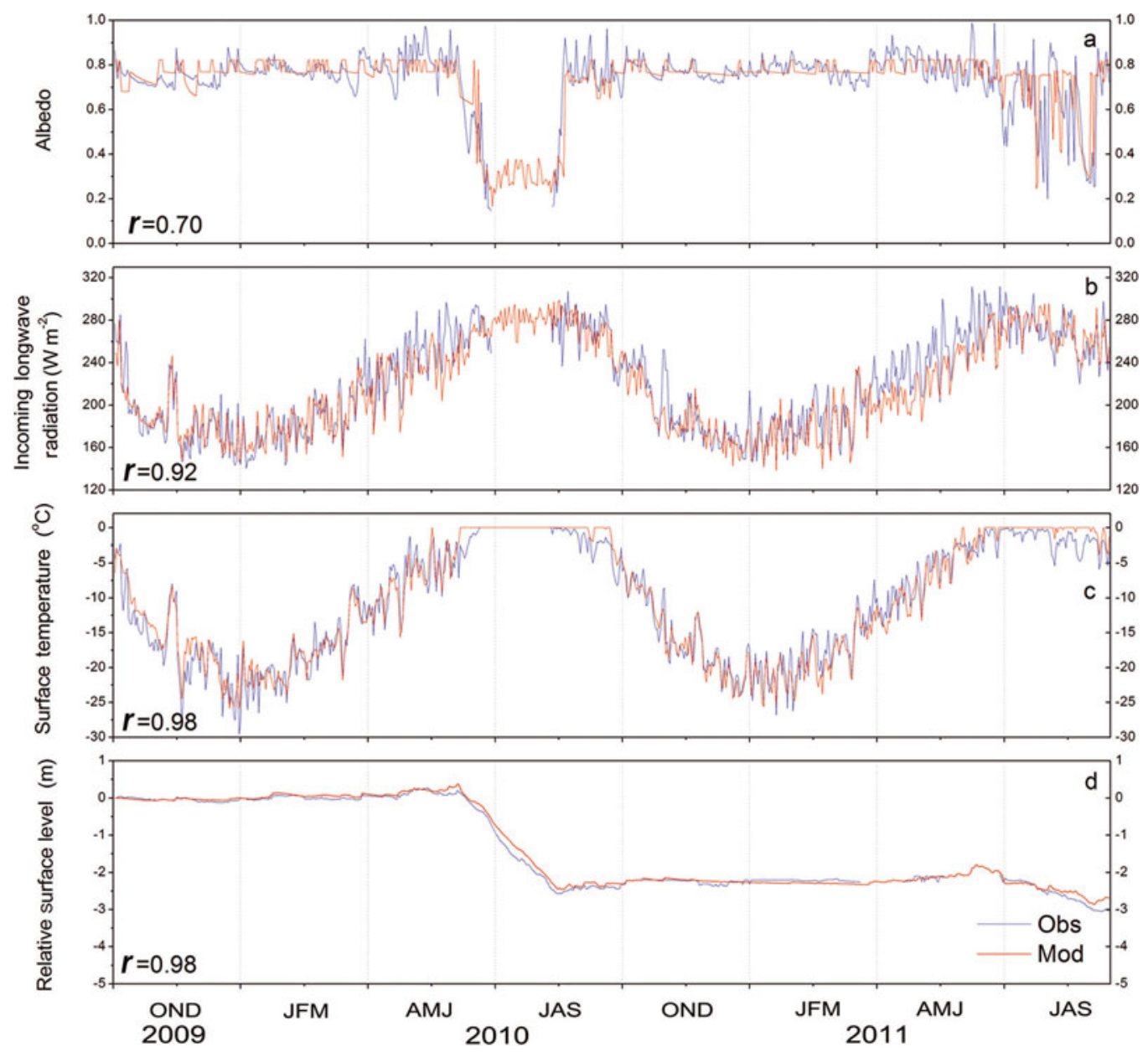

Fig. 4. Observed and modelled daily (a) albedo, (b) incoming longwave radiation, (c) surface temperature and (d) height from the sonic ranger sensor to Zhadang glacier surface and their correlation coefficient at the site AWS2 for 4 October 2009 to 15 September 2011 . Ice albedo calculated as a function of daily dew-point temperature $\left(T_{\mathrm{W}}\right)$ : $-0.0536^{\circ} \mathrm{C}^{-1} T_{\mathrm{W}}+0.4681$, which was gained from the correlation of observed ice albedo and $T_{\mathrm{W}}$ during summer 2011. (OND = October to December, etc.)

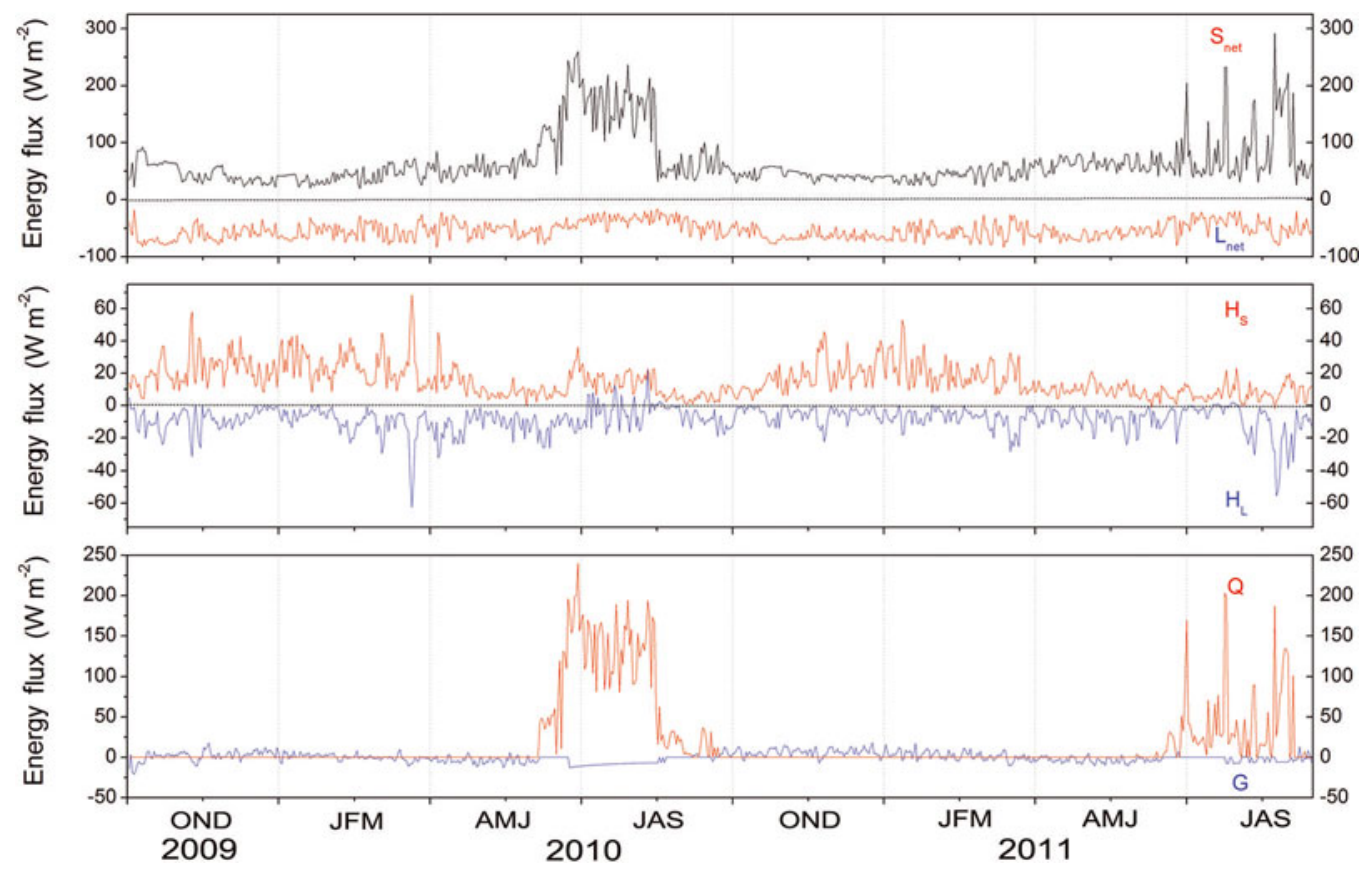

Fig. 5. Daily mean values of energy-balance components at site AWS2 for 4 October 2009 to 15 September 2011. $S_{\text {net }}$ is net shortwave radiation, $L_{\text {net }}$ is net longwave radiation, $H_{\mathrm{S}}$ is sensible heat flux, $H_{\mathrm{L}}$ is latent heat flux, $G$ is subsurface conductive heat flux and $Q$ is the melting component. (OND = October to December, etc.) 
Table 2. Mean seasonal values of energy-flux components $\left(\mathrm{W} \mathrm{m}^{-2}\right)$

\begin{tabular}{|c|c|c|c|c|c|c|}
\hline \multirow[t]{2}{*}{ Energy-flux component } & \multicolumn{2}{|c|}{$2009 / 10$} & \multicolumn{2}{|c|}{ 2010/11 } & \multirow[t]{2}{*}{ Winter average } & \multirow[t]{2}{*}{ Summer average } \\
\hline & Winter (Oct-Apr) & Summer (May-Sept) & Winter (Oct-Apr) & Summer (May-Sept) & & \\
\hline$S_{\text {in }}$ & 200 & 255 & 208 & 274 & 204 & 264 \\
\hline$S_{\text {out }}$ & -155 & -148 & -162 & -197 & -159 & -172 \\
\hline$L_{\text {in }}$ & 191 & 264 & 187 & 258 & 189 & 261 \\
\hline$L_{\text {out }}$ & -249 & -309 & -247 & -307 & -248 & -308 \\
\hline$S_{\text {net }}$ & 45 & 107 & 46 & 77 & 46 & 92 \\
\hline$L_{\text {net }}$ & -58 & -45 & -60 & -50 & -59 & -47 \\
\hline$H_{\mathrm{S}}$ & 22 & 10 & 18 & 8 & 20 & 9 \\
\hline$H_{\mathrm{L}}$ & -10 & -8 & -7 & -10 & -9 & -9 \\
\hline$G$ & 0 & -4 & 3 & -2 & 2 & -3 \\
\hline$Q$ & 0 & 61 & 0 & 24 & 0 & 43 \\
\hline
\end{tabular}

contribute to the larger values of both $H_{\mathrm{S}}$ and $H_{\mathrm{L}}$ in winter than in summer. The sign of the subsurface heat flux $(G)$, which shifted from positive to negative, is a function of the annual energy cycle. A positive value for $G$ suggests that subsurface cold content accumulated during winter, whereas a negative $G$ implies the release of cold content in summer. As a result of the energy balance, positive melt heat flux $(Q)$, with almost the same oscillation trend as $S_{\text {net, }}$ occurred only in summer.

Table 4 lists the contributions of energy-flux components to total heat flux. For the whole period of observation, the radiation heat flux $\left(\left|S_{\text {net }}\right|+\left|L_{\text {net }}\right|\right)$ accounted for $82 \%$ of the total heat flux and was the most important heat-flux component. Turbulent sensible and latent heat flux followed at $10 \%$ and $6 \%$, respectively. The subsurface heat flux $(2 \%)$ contributed little of the energy-flux components to the total heat flux throughout the study. These fluxes exhibited the same order-of-magnitude contribution in both winter and summer. The main seasonal variation in the energy balance during the study period is found in two radiation components: net shortwave radiation and net longwave radiation. During the winter season, $L_{\text {net }}$ dominated the radiation heat-flux component, but $S_{\text {net }}$ became more important during the summer season.

\section{Glacier mass balance}

Table 5 lists the calculated mass-balance components at the AWS2 site. The results show that most of the precipitation occurred during summer: $80 \%$ and $87 \%$ in 2010 and 2011, respectively. The minor part of the precipitation that fell during winter was all in the form of snowfall. During summer, $74 \%$ and $85 \%$ of the precipitation was in the form

Table 3. Seasonal mean values of meteorological variables

\begin{tabular}{|c|c|c|c|c|}
\hline \multirow[t]{2}{*}{ Factor } & \multicolumn{2}{|c|}{$2009 / 10$} & \multicolumn{2}{|c|}{$2010 / 11$} \\
\hline & Winter (Oct-Apr) & Summer (May-Sept) & Winter (Oct-Apr) & Summer (May-Sept) \\
\hline Air temperature $\left({ }^{\circ} \mathrm{C}\right)$ & -10.2 & 1.2 & -11.4 & 0.6 \\
\hline Relative humidity (\%) & 34.7 & 70.4 & 41.6 & 69.9 \\
\hline Wind speed $\left(\mathrm{ms}^{-1}\right)$ & 3.9 & 3.1 & 3.5 & 3.2 \\
\hline Albedo & 0.8 & 0.6 & 0.8 & 0.7 \\
\hline Cloud coverage* & 0.3 & 0.4 & 0.3 & 0.4 \\
\hline$\delta T(\mathrm{~K})^{\dagger}$ & 5.8 & 2.7 & 5.1 & 2.5 \\
\hline
\end{tabular}

*Cloud coverage was calculated as $(1-\mathrm{clf}) /\left(\mathrm{clf}_{\max }-\mathrm{clf}_{\min }\right) \times 100 \%$ where clf is the ratio of the measured incoming shortwave radiation to the incoming shortwave radiation at the top of the atmosphere, and $\mathrm{clf}_{\min }$ and $\mathrm{clf}_{\max }$ are the calculated minimum and maximum values of clf within the study period, respectively.

'Denotes the difference between air temperature and surface temperature.

Table 4. Seasonal energy fluxes at the glacier surface and proportional contribution of each flux

\begin{tabular}{|c|c|c|c|c|c|c|c|}
\hline \multirow[t]{2}{*}{ Mass-balance year } & \multirow[t]{2}{*}{ Season } & Sum* & $S_{\text {net }}$ & $L_{\text {net }}$ & $H_{\mathrm{S}}$ & $H_{\mathrm{L}}$ & $G$ \\
\hline & & $\mathrm{W} \mathrm{m}^{-2}$ & $\%$ & $\%$ & $\%$ & $\%$ & $\%$ \\
\hline \multirow[t]{2}{*}{$2009 / 10$} & Winter & 136 & 33 & 42 & 16 & 8 & 0 \\
\hline & Summer & 173 & 62 & 26 & 6 & 4 & 2 \\
\hline \multirow[t]{2}{*}{ 2010/11 } & Winter & 134 & 35 & 45 & 13 & 5 & 2 \\
\hline & Summer & 147 & 52 & 34 & 6 & 7 & 2 \\
\hline All observed periods & - & 148 & 45 & 37 & 10 & 6 & 2 \\
\hline
\end{tabular}

*Sum is the sum of the energy fluxes in absolute values: $\left|S_{\text {net }}\right|+\left|L_{\text {net }}\right|+\left|H_{\mathrm{S}}\right|+\left|H_{\mathrm{L}}\right|+|G|$; proportional contribution of each flux was calculated as $\mid$ energy flux $\mid /$ sum. 


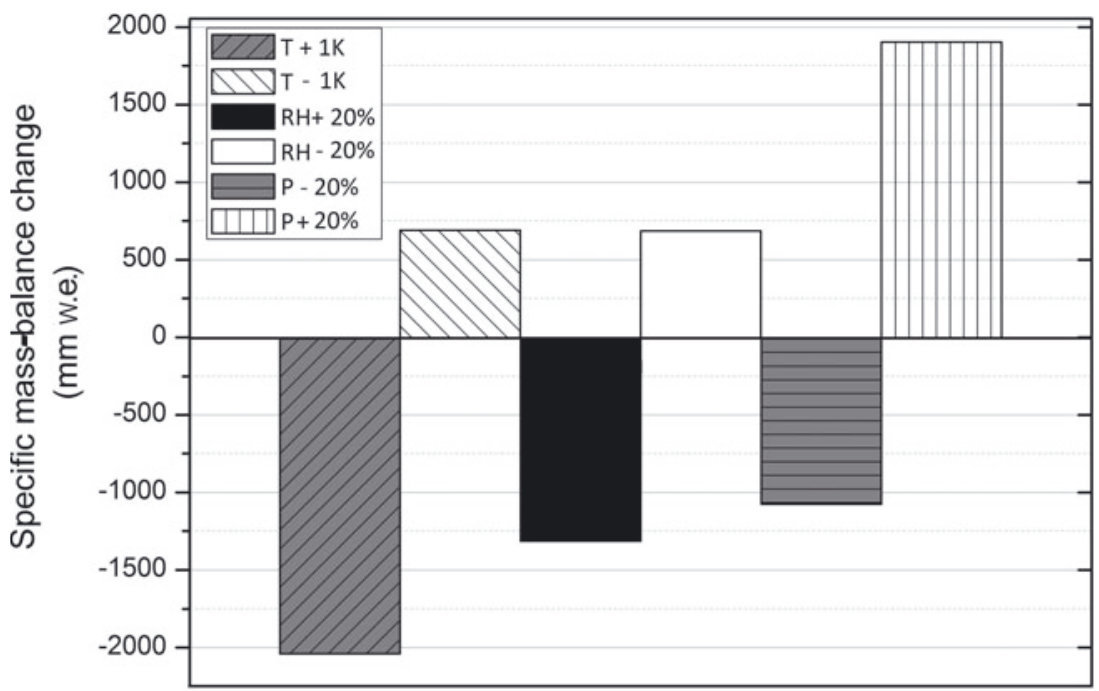

Fig. 6. The sensitivity of specific mass balance was examined by perturbations of temperature $( \pm 1 \mathrm{~K})$, relative humidity ( $\pm 20 \%)$ and precipitation $( \pm 20 \%)$. The results show that the specific mass balance is more sensitive to changes in precipitation than other variables.

of snow in 2010 and 2011, respectively. Because of strong melting in summer, nearly all of the penetration water (rainfall and meltwater) ran off as discharge and only a small amount $(117 \mathrm{~mm}$ w.e. in 2010 and $104 \mathrm{~mm}$ w.e. in 2011) was refrozen as superimposed ice. Seasonal variations in evaporation (sublimation) during the study period were subtle (average value of $100 \mathrm{~mm}$ w.e. for the 2 years). Although the mass balance was positive in both winters, the large mass deficits in summer resulted in negative annual mass balances of -1968 and $-432 \mathrm{~mm}$ w.e., respectively, for the two years at this site.

\section{DISCUSSION}

\section{Sensitivity of mass balance to meteorological variables}

In order to test the sensitivity of mass balance to meteorological variables, test cases were prescribed. Here we altered the air temperature by $\pm 1^{\circ} \mathrm{C}$, relative humidity by $\pm 20 \%$ and precipitation by $\pm 20 \%$ throughout the period. The mass-balance change then reflects its sensitivity to the perturbation of variables. As shown in Figure 6, $2.04 \mathrm{~m}$ w.e. more meltwater (an increase of $85 \%$ ) would run off at the observation site if the air temperature was increased by $1 \mathrm{~K}$, while 0.69 mw.e. (29\%) of snow or ice would melt if air temperature was decreased by $1 \mathrm{~K}$. Air temperature, as a key factor, will particularly control when melt commences and how fast the winter snowpack is removed. Since lower ice albedo will amplify ablation (Andreassen and others, 2008), increasing temperature will not only increase ice ablation but also prolong the melt season. Thus mass balance is more affected by an air temperature perturbation of $+1 \mathrm{~K}$ than by a perturbation of $-1 \mathrm{~K}$, especially in the ablation area of the glacier.

The mass-balance changes for perturbations of relative humidity $(\mathrm{RH})$ are $-1.3 \mathrm{~m}$ w.e. (55\%) and $0.68 \mathrm{~m}$ w.e. $(29 \%)$ for $+20 \%$ and $-20 \%$ humidity perturbations, respectively. Previous studies also show the sensitivity of glacier mass balance to changes in moisture (Wagnon and others, 1999, 2001; Francou and others, 2003; Mölg and others, 2003). An increase of $20 \%$ in precipitation directly influences the amount of accumulation, but also changes the albedo and thus the melting. More snowfall increases surface albedo and reduces the main energy source (net shortwave radiation), leading to less ablation (Mölg and others, 2008). The sensitivity to a $\pm 20 \%$ change in precipitation is higher than for a $1 \mathrm{~K}$ change in temperature. The results show that the model is nearly twice as sensitive to a $20 \%$ change in precipitation as to a $20 \%$ change in relative humidity.

Table 5. Calculated annual and seasonal mass-balance components at site AWS2: mass balance=precipitation-runoff-evaporation; runoff $=$ rainfall + meltwater - refrozen water $(\mathrm{mm}$ w.e. $)$

\begin{tabular}{|c|c|c|c|c|c|c|}
\hline \multirow[t]{2}{*}{ Mass-balance component } & \multicolumn{2}{|c|}{$2009 / 10$} & \multicolumn{2}{|c|}{$2010 / 11$} & \multirow[t]{2}{*}{$2009 / 10$} & \multirow[t]{2}{*}{$2010 / 11$} \\
\hline & Winter (Oct-Apr) & Summer (May-Sept) & Winter (Oct-Apr) & Summer (May-Sept) & & \\
\hline Precipitation & 112 & 456 & 64 & 423 & 568 & 487 \\
\hline Rainfall & 0 & 118 & 0 & 63 & 118 & 63 \\
\hline Snowfall & 112 & 338 & 64 & 360 & 450 & 424 \\
\hline Meltwater & 0 & 2427 & 0 & 867 & 2427 & 867 \\
\hline Refrozen water & 0 & 117 & 0 & 104 & 117 & 104 \\
\hline Runoff & 0 & 2428 & 0 & 826 & 2428 & 826 \\
\hline Evaporation & 69 & 40 & 46 & 46 & 109 & 92 \\
\hline Mass balance & 43 & -2012 & 18 & -449 & -1969 & -431 \\
\hline
\end{tabular}




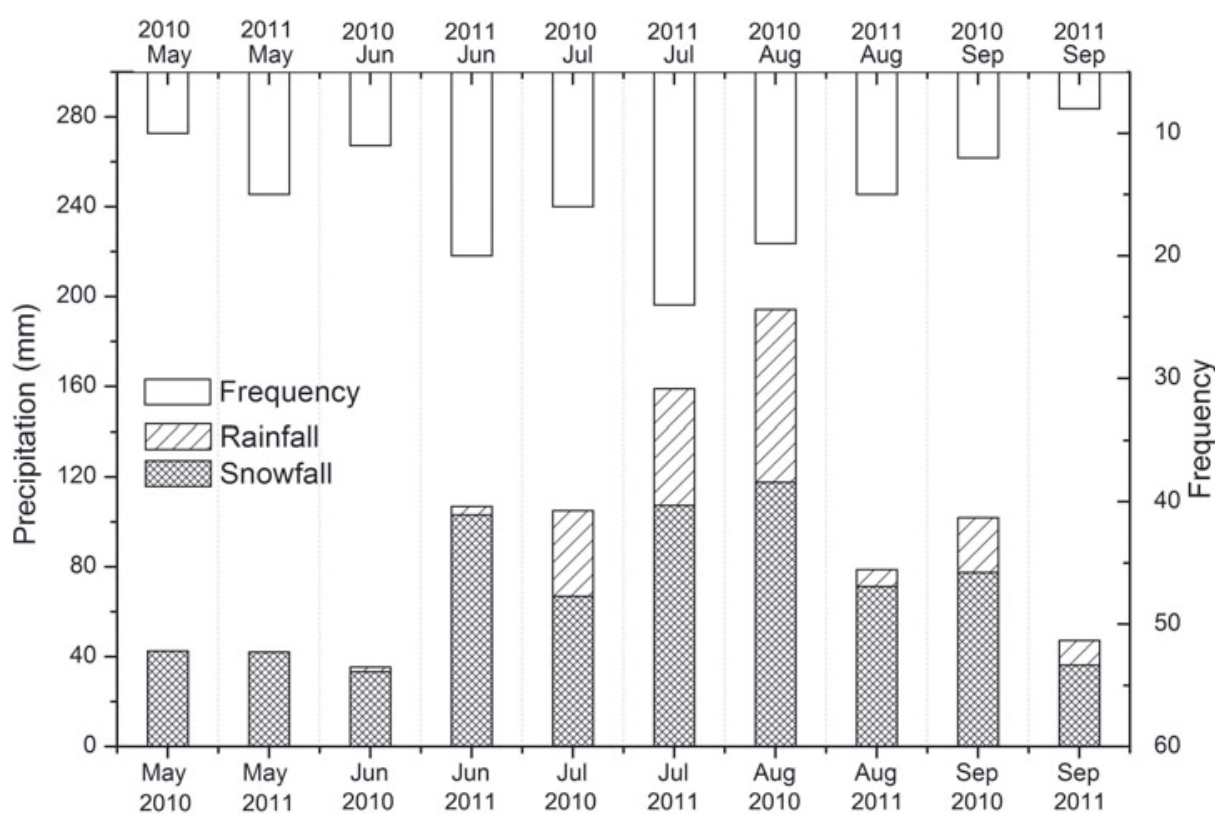

Fig. 7. The monthly amount, form and frequency of precipitation in the summers of 2010 and 2011. Frequency was calculated as the number of daily precipitation events per month.

\section{Typical features of the energy and mass balance on Zhadang glacier}

Zhadang glacier is subject to particular seasonal climatic conditions that induce seasonal circumstances of energy and mass balance. In winter, negative $L_{\text {net, }}$ the dominant radiation component, caused net radiation to be negative. This part of the energy sink was compensated by positive turbulent heat flux $\left(H_{\mathrm{S}}+H_{\mathrm{L}}\right)$ and subsurface heat flux $G$. Thus, no melting occurred in winter. The sign of $H_{\mathrm{L}}$ (negative) indicates that the only mass loss during winter was in the form of sublimation. In summer, positive $S_{\text {net, }}$ the most significant heat flux, together with $H_{\mathrm{S}}$ contributed to positive $Q$ for glacier surface melting. The energy released by condensation, positive $H_{\mathrm{L}}$ (see Fig. 5), enhanced surface melting during midsummer (Oerlemans, 2000; Giesen and others, 2008, 2009). As a result, strong summertime melting occurred on the glacier surface in the ablation zone.

\section{Changes in summer climates and their influence on mass balance}

The monthly frequency, total amount and form of precipitation during the summer (May-October) are shown in Figure 7. According to Chang and Chen (1995), the warm wet airflow of the Indian monsoon begins in mid-June, which is thus the beginning of the precipitation season. The precipitation monthly distribution implied that the Indian monsoon started a month later than usual in 2010. In contrast, the precipitation increased dramatically in June 2011, indicating that the Indian monsoon invaded the region. Subsequently, the monsoon became strongest with the highest rate of precipitation in July, followed by a weakening in August. Yang and others (2011) reported that glacier surface energy- and mass-balance variations were related to the progress of the Indian monsoon during the melting season in southeast Tibet. Monthly mean values of energy-balance components and mass balance are presented in Figure 8 and Table 6, respectively. In May 2010 and 2011, the energy input as net radiation and $H_{\mathrm{S}}$ were entirely consumed by $H_{\mathrm{L}}$ (sublimation) and $G$ (as cold content release) and therefore no melting occurred. All snowfall contributed to mass accumulation. Thus, positive mass balance was shown on the glacier surface (also shown by the variation in snow depth in Fig. 9). With increasing sun elevation and air temperature in June, positive $Q$ emerged on the glacier surface at the beginning of the melting season. In June 2010, a large amount of net shortwave radiation $\left(71 \mathrm{~W} \mathrm{~m}^{-2}\right)$ was available for melting on the glacier surface due to early exposure of the ice surface (Fig. 9). In contrast, intense snowfall ensured that the glacier surface was covered with snow (albedo $=0.8$ ) in June 2011. The snow surface reflected most of $S_{\text {in, }}$ and as a result only a small amount became melt heat flux $Q\left(8 \mathrm{~W} \mathrm{~m}^{-2}\right)$. Therefore, distinctly different mass-balance results were found in the two years: $-452 \mathrm{~mm}$ w.e. in June 2010 and $98 \mathrm{~mm}$ w.e. in June 2011. In July 2010, with increasing air temperature, the amount of snowfall was small. Thus, the ice-dominated glacier surface (average albedo of 0.3 ) absorbed most of $S_{\text {in, }}$ and strong melting $\left(Q=141 \mathrm{~W} \mathrm{~m}^{-2}\right)$ occurred on the surface, causing a huge mass deficit of $-1076 \mathrm{~mm}$ w.e. In July 2011 , the thin snow layer $(\alpha=0.7)$ from frequent snowfall kept $S_{\text {net }}$ at a low level and resulted in a low melting rate on the surface $\left(Q=46 \mathrm{~W} \mathrm{~m}^{-2}\right)$ and a consequent mass-balance result of $-258 \mathrm{~mm}$ w.e. In August 2010, precipitation reached its highest amount. Although nearly half of the precipitation was rainfall, snowfall still kept the surface at a relatively high albedo (0.5) and resulted in a large amount of $S_{\text {net }}\left(S_{\text {net }}=109 \mathrm{~W} \mathrm{~m}^{-2}\right)$. Cloudy conditions (clf $\left.=61.5 \%\right)$ also enhanced $L_{\text {in }}$ and provided a positive effect for melting. Furthermore, the positive $H_{\mathrm{L}}$ at the beginning of August (Fig. 5) also made a positive contribution to surface melting. As a result, there was still a large melt heat flux $\left(84 \mathrm{~W} \mathrm{~m}^{-2}\right)$, which resulted in a mass balance of $-542 \mathrm{~mm}$ w.e. during August 2010. In August 2011, due to less snowfall, a lowalbedo surface (0.6) absorbed the largest amount of $S_{\text {in }}$ $\left(S_{\text {net }}=108 \mathrm{~W} \mathrm{~m}^{-2}\right)$ compared with former months and also led to the largest net radiation $\left(57 \mathrm{~W} \mathrm{~m}^{-2}\right)$. However, evaporation was also largest at this time and shared $-17 \mathrm{~W} \mathrm{~m}^{-2}$ of heat flux going into evaporation. The outcome 


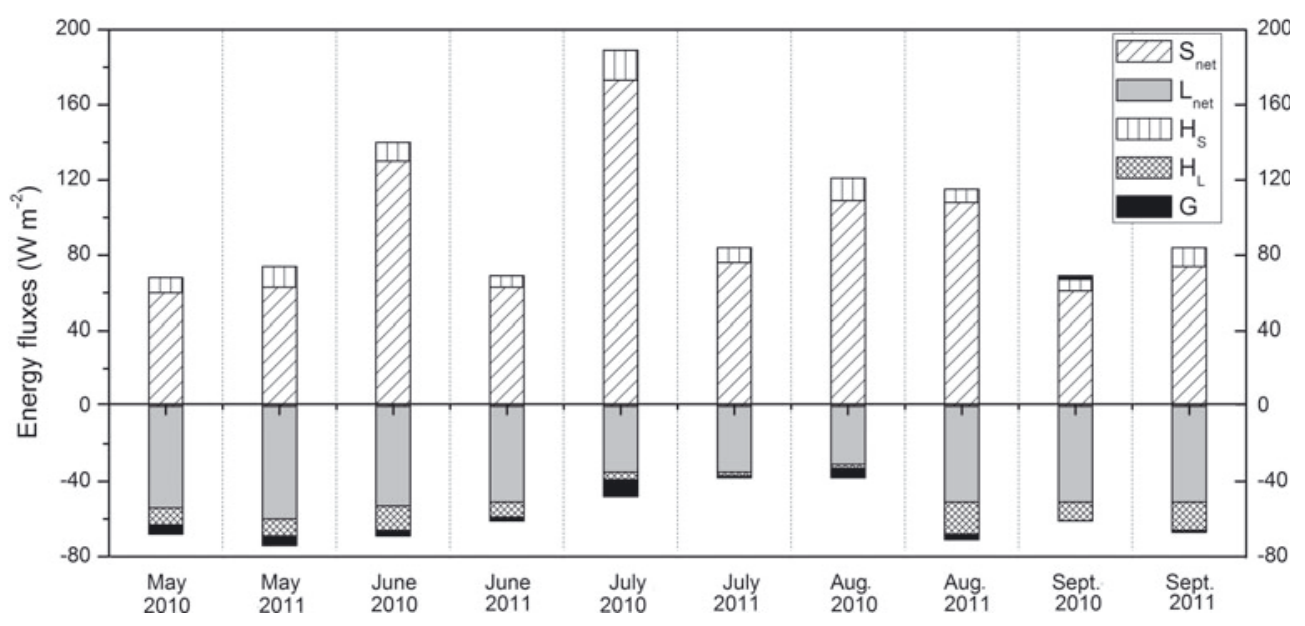

Fig. 8. Monthly mean energy components of the glacier surface for summer (September 2011: for the interval 1-15 September).

of the energy balance was a $44 \mathrm{~W} \mathrm{~m}^{-2}$ heat flux available for melting and a mass balance of $-292 \mathrm{~mm}$ w.e. during August 2011. The small positive mass balance in September marked the end of the melt season for that year.

Although the precipitation sum was almost the same in both summers (456 mmw.e. in 2010 and $423 \mathrm{~mm}$ w.e. in 2011) there was a distinct mass-balance difference between the summers of 2010 (-2011 mm w.e.) and 2011 ( $-449 \mathrm{~mm}$ w.e.). Fujita (2000) pointed out that some precipitation (rain) fails to contribute to the accumulation, but snowfall keeps the albedo high and largely limits ablation during the melt season on SAT glaciers. Thus, SAT glaciers are more vulnerable than winter-accumulation-type glaciers. This is because the increase in air temperature causes a decrease in accumulation and a drastic increase in ablation with lowering albedo. This was the situation on Zhadang glacier during the summer of 2010. A study on Glaciar Zongo, Bolivia (Sicart and others, 2011), suggests that melt is reduced by snowfall during the wet season via the albedo effect during the melt season. We thus conclude that SAT glaciers are very sensitive to variations of precipitation seasonality (or monthly distribution) and form (proportion of snowfall and rainfall) as suggested by previous studies (e.g. Kang and others, 2009).

\section{CONCLUSIONS}

A physically based energy-balance model with forcing data including air temperature, humidity, wind speed, global radiation and precipitation was used to calculate the surface energy balance at site AWS2 on Zhadang glacier over
2 years. The calculated surface albedo, incoming longwave radiation, surface temperature and surface height corresponded well with observed values. The results indicate that the model is reliable enough to make robust calculations of surface energy and mass balance. For the whole observation period, the radiation component dominated $(82 \%)$ the total surface energy heat fluxes. Turbulent sensible (10\%) and turbulent latent heat flux (6\%) followed. Subsurface heat flux represented a very minor proportion $(2 \%)$ of the total heat flux. The main seasonal variations in energy fluxes were caused by changes in net shortwave and longwave radiation and these led to different mass-balance results. In winter, dominant negative net longwave radiation resulted in negative net all-wave radiation. This energy sink was offset by positive turbulent and subsurface heat fluxes, and no melt occurred in winter. In summer, net shortwave radiation was the most important radiation component and caused positive net radiation. The positive radiation heat flux, together with positive turbulent heat flux, provided the melt heat flux for surface melting. The dramatic differences in summer mass balance between 2010 and 2011 indicate that the glacier surface mass balance was closely related to precipitation seasonality and form. The present study suggests that glacier mass-balance models that use annual variations as input factors, rather than seasonal or monthly variations, may err significantly in their estimates of massbalance variability on SAT glaciers. To better describe the evolution of summer-accumulation glacier surface, high time resolution precipitation data are necessary during the calculation of glacier surface mass balance.

Table 6. Monthly mean values of meteorological factors, melt heat flux and mass balance during summer

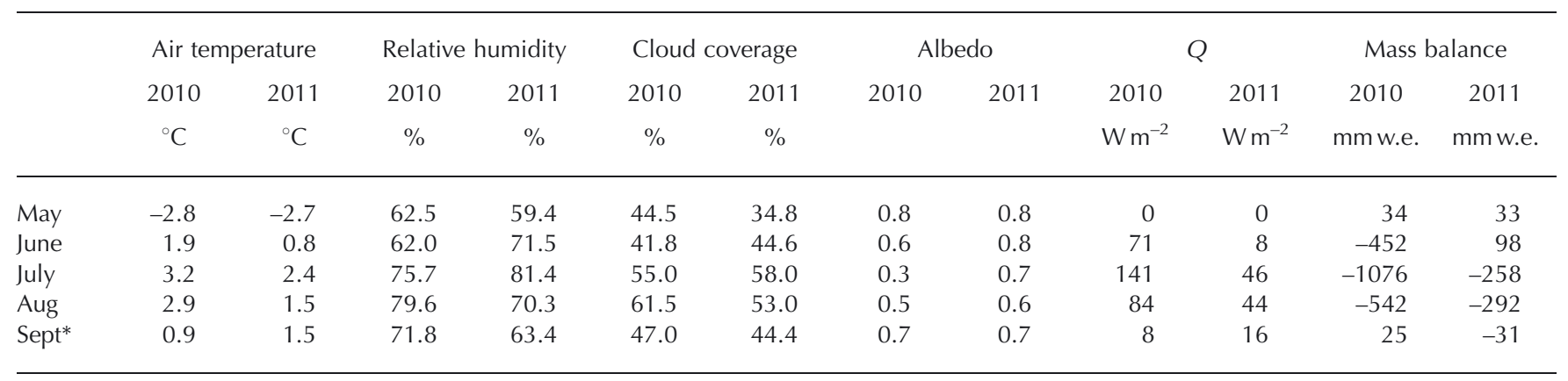

*For the interval 1-15 September 2011. 


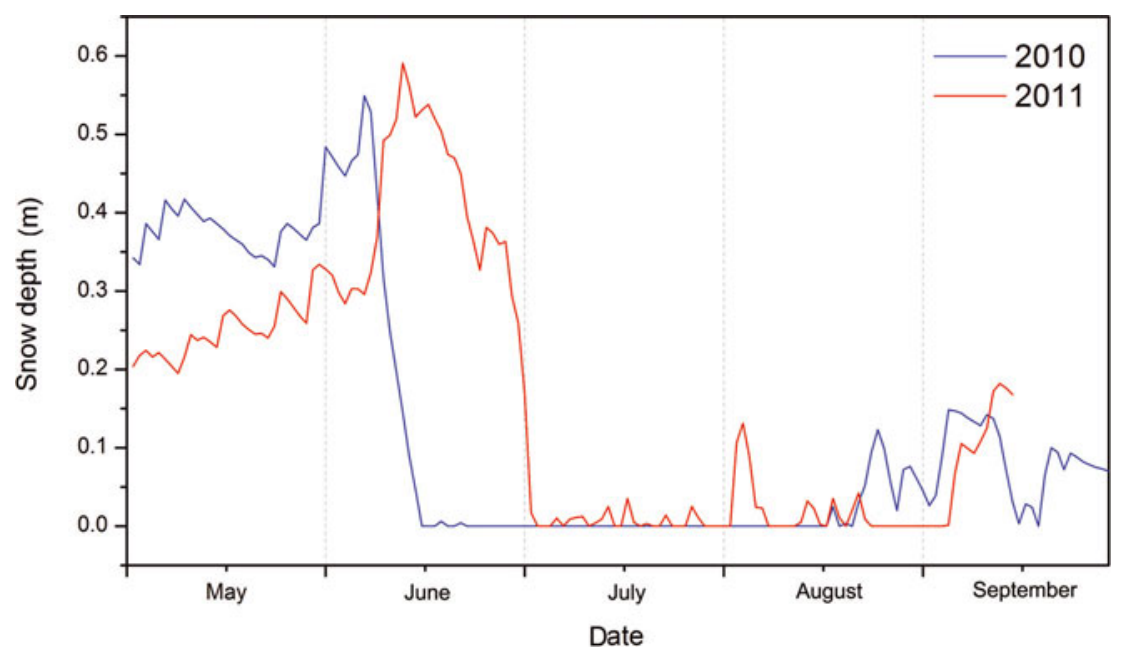

Fig. 9. Daily snow depth over the glacier ice at AWS2 during the summers of 2010 and 2011.

\section{ACKNOWLEDGEMENTS}

This work is supported by the Global Change Research Program of China (2010CB951401), the National Natural Science Foundation of China (41190081, 41225002) and the German Research Foundation (DFG) within the Tibetan Plateau Priority Programme (TiP) (SCHE 750/4-1, SCHN 680/ 3-1 and BU 949/20-1). We thank colleagues working at Nam Co station.

\section{REFERENCES}

Ageta $\mathrm{Y}$ and Higuchi K (1984) Estimation of mass balance components of a summer-accumulation type glacier in the Nepal Himalaya. Geogr. Ann. A, 66(3), 249-255

Andreas EL (1987) A theory for the scalar roughness and the scalar transfer coefficients over snow and sea ice. Bound.-Layer Meteorol., 38(1-2), 159-184 (doi: 10.1007/BF00121562)

Andreassen LM, Van den Broeke MR, Giesen RH and Oerlemans J (2008) A 5 year record of surface and mass-balance from the ablation zone of Storbreen, Norway. J. Glaciol., 54(185), 245-258 (doi: 10.3189/002214308784886199)

Bolch T and 7 others (2010) A glacier inventory for the western Nyainqentanglha Range and Nam Co Basin, Tibet, and glacier changes 1976-2009. Cryosphere, 4(2), 429-467

Bolch Tand 10 others (2012) The state and fate of Himalayan glaciers. Science, 336(6079), 310-314 (doi: 10.1126/science.1215828)

Braithwaite RJ and Olesen OB (1990) A simple energy-balance model to calculate ice ablation at the margin of the Greenland ice sheet. J. Glaciol., 36(123), 222-228

Braithwaite RJ, Laternser M and Pfeffer WT (1994) Variations of near-surface firn density in the lower accumulation area of the Greenland ice sheet, Pâkitsoq, West Greenland. J. Glaciol., 40(136), 477-485

Brock BW, Willis IC and Sharp MJ (2000) Measurement and parameterization of albedo variations at Haut Glacier d'Arolla, Switzerland. J. Glaciol., 46(155), 675-688 (doi: 10.3189/ 172756500781832675)

Brutsaert W (1975) On a derivable formula for long-wave radiation from clear skies. Water Resour. Res., 11(5), 742-744 (doi: 10.1029/WR011i005p00742)

Chang C-P and Chen GTJ (1995) Tropical circulations associated with southwest monsoon onset and westerly surges over the South China Sea. Mon. Weather Rev., 123(11), 3254-3267 (doi: 10.1175/1520-0493(1995)123<3254:TCAWSM>2.0.CO;2)

Chen F, Kang S, Zhang Y and You Q (2009) Glaciers and lake change in response to climate change in the Nam Co Basin, Tibet. J. Mt. Sci. [China], 27(6), 641-647
Crawford TM and Duchon CE (1999) An improved parameterization for estimating effective atmospheric emissivity for use in calculating daytime downwelling longwave radiation. J. Appl. Meteorol., 38(4), 474-480

Curry JA and Webster PJ (1999) Thermodynamics of atmospheres and oceans. Academic Press, San Diego, CA

Francou B, Vuille M, Wagnon P, Mendoza J and Sicart JE (2003) Tropical climate change recorded by a glacier in the central Andes during the last decades of the twentieth century: Chacaltaya, Bolivia, $16^{\circ} \mathrm{S}$. J. Geophys. Res., 108(D5), 4154 (doi: 10.1029/2002JD002959)

Fujita K (2007) Effect of dust event timing on glacier runoff: sensitivity analysis for a Tibetan glacier. Hydrol. Process., 21(21), 2892-2896 (doi: 10.1002/hyp.6504)

Fujita K (2008) Effect of precipitation seasonality on climatic sensitivity of glacier mass balance. Earth Planet. Sci. Lett., 276(1-2), 14-19 (doi: 10.1016/j.epsl.2008.08.028)

Fujita K and Ageta Y (2000) Effect of summer accumulation on glacier mass balance on the Tibetan Plateau revealed by massbalance model. J. Glaciol., 46(153), 244-252 (doi: 10.3189/ 172756500781832945)

Fujita K, Seko K, Ageta Y, Pu J and Yao T (1996) Superimposed ice in glacier mass balance on the Tibetan Plateau. J. Glaciol., 42(142), 454-460

Fujita K, Ohta T and Ageta Y (2007) Characteristics and climatic sensitivities of runoff from a cold-type glacier on the Tibetan Plateau. Hydrol. Process., 21(21), 2882-2891 (doi: 10.1002/ hyp.6505)

Fukami H, Kojima K and Aburakawa H (1985) The extinction and absorption of solar radiation within a snow cover. Ann. Glaciol., 6, 118-122

Giesen RH, Van den Broeke MR, Oerlemans J and Andreassen LM (2008) Surface energy balance in the ablation zone of Midtdalsbreen, a glacier in southern Norway: interannual variability and the effect of clouds. J. Geophys. Res., 113(D21), D21111 (doi: 10.1029/2008JD010390)

Giesen RH, Andreassen LM, Van den Broeke MR and Oerlemans J (2009) Comparison of the meteorology and surface energy balance at Storbreen and Midtdalsbreen, two glaciers in southern Norway. Cryosphere, 3(1), 57-74

Hobbs PV (1974) Ice physics. Clarendon Press, Oxford

Hock R (2005) Glacier melt: a review on processes and their modelling. Progr. Phys. Geogr., 29(3), 362-391 (doi: 10.1191/ 0309133305pp453ra)

Hock R and Holmgren B (2005) A distributed surface energybalance model for complex topography and its application to Storglaciären, Sweden. J. Glaciol., 51(172), 25-36 (doi: 10.3189/172756505781829566) 
Immerzeel WW, Van Beeke LPH and Bierkens MFP (2010) Climate change will affect the Asian water towers. Science, 328(5984), 1382-1385

Kang S and 6 others (2009) Correspondence. Early onset of rainy season suppresses glacier melt: a case study on Zhadang glacier, Tibetan Plateau. J. Glaciol., 55(192), 755-758 (doi: 10.3189/ 002214309789470978)

Kang S, Xu Y, You Q, Flügel W-A, Pepin N and Yao T (2010) Review of climate and cryospheric change in the Tibetan Plateau. Environ. Res. Lett., 5(1) (doi: 10.1088/1748-9326/5/1/015101)

Kayastha RB, Ohata T and Ageta Y (1999) Application of a massbalance model to a Himalayan glacier. J. Glaciol., 45(151), 559-567

Kondo J and Yamazawa H (1986) Bulk transfer coefficient over a snow surface. Bound.-Layer Meteorol., 34(1-2), 123-135

Li X and 9 others (2008) Cryospheric change in China. Global Planet. Change, 62(3-4), 210-218 (doi: 10.1016/j.gloplacha. 2008.02.001)

Liu X and Chen B (2000) Climatic warming in the Tibetan Plateau during recent decades. Int. J. Climatol., 20(14), 1729-1742

Marsh P and Woo MK (1984) Wetting front advance and freezing of meltwater within a snow cover. 1. Observations in the Canadian Arctic. Water Resour. Res., 20(12), 1853-1864

Maussion Fand 9 others (2011) Glaciological field studies at Zhadang glacier (5500-6095 m), Tibetan Plateau. In Workshop on the use of automatic measuring systems on glaciers. IASC Workshop, 23-26 March 2011, Pontresina (Switzerland). Institute for Marine and Atmospheric Research, Utrecht University, Utrecht, 62-68

Mellor M (1977) Engineering properties of snow. J. Glaciol., 19(81), 15-66

Mölg T, Georges C and Kaser G (2003) The contribution of increased incoming shortwave radiation to the retreat of the Rwenzori glaciers, East Africa, during the 20th century. Int. J. Climatol., 23(3), 291-303

Mölg T, Cullen NJ, Hardy DR, Kaser G and Klok L (2008) Mass balance of a slope glacier on Kilimanjaro and its sensitivity to climate. Int. J. Climatol., 28, 881-892 (doi: 10.1002/joc.1589)

Oerlemans J (2000) Analysis of a 3 year meteorological record from the ablation zone of Morteratschgletscher, Switzerland: energy and mass balance. J. Glaciol., 46(155), 571-579 (doi: 10.3189/ 172756500781832657)

Oerlemans J and Knap WH (1998) A 1 year record of global radiation and albedo in the ablation zone of Morteratschgletscher, Switzerland. J. Glaciol., 44(147), 231-238

Pfeffer WT and Humphrey NF (1996) Determination of timing and location of water movement and ice-layer formation by temperature measurements in sub-freezing snow. J. Glaciol., 42(141), 292-304

Sakai A, Fujita K, Duan K, Pu J, Nakawo M and Yao T (2006) Five decades of shrinkage of July 1 st glacier, Qilian Shan, China. J. Glaciol., 52(176), 11-16 (doi: 10.3189/ 172756506781828836)

Sakai A, Fujita K, Nakawo M and Yao T (2009) Simplification of heat balance calculation and its application to the glacier runoff from the July 1 st Glacier in northwest China since the 1930s. Hydrol. Process., 23(4), 585-596 (doi: 10.1002/hyp.7187)

Schneider T and Jansson P (2004) Internal accumulation in firn and its significance for the mass balance of Storglaciären, Sweden. J. Glaciol., 50(168), 25-34 (doi: 10.3189/ 172756504781830277)

Shi Y and Liu S (2000) Estimation on the response of glaciers in China to the global warming in the 21st century. Chinese Sci. Bull., 45(7), 668-672 (doi: 10.1007/BF02886048) [in Chinese]

Sicart JE, Hock R, Ribstein P and Chazarin JP (2010) Sky longwave radiation on tropical Andean glaciers: parameterization and sensitivity to atmospheric variables. J. Glaciol., 56(199), 854-860 (doi: 10.3189/002214310794457182)

Sicart JE, Hock R, Ribstein P, Litt M and Ramirez E (2011) Analysis of seasonal variations in mass balance and meltwater discharge of the tropical Zongo Glacier by application of a distributed energy balance model. J. Geophys. Res., 116(D13), D13105 (doi: 10.1029/2010JD015105)

Takahashi S, Ohata T and Xie Y (1989) Characteristics of heat and water fluxes on glacier and ground surfaces in the West Kunlun Mountains. Bull. Glacier Res., 7, 89-98

US Army Corps of Engineers (1956) Snow hydrology: summary report of the snow investigations. North Pacific Division, US Army Corps of Engineers, Portland, OR

Van de Wal RSW, Oerlemans J and Van der Hage JC (1992) A study of ablation variations on the tongue of Hintereisferner, Austrian Alps. J. Glaciol., 38(130), 319-324

Van den Broeke MR, Van As D, Reijmer C and Van de Wal R (2004) Assessing and improving the quality of unattended radiation observations in Antarctica. J. Atmos. Oceanic Technol., 21(9), 1417-1431

Wagnon P, Ribstein P, Kaser G and Berton P (1999) Energy balance and runoff seasonality of a Bolivian glacier. Global Planet. Change, 22(1-4), 49-58

Wagnon P, Ribstein P, Francou B and Sicart JE (2001) Anomalous heat and mass budget of Glaciar Zongo, Bolivia, during the 1997/98 El Niño year. J. Glaciol., 47(156), 21-28 (doi: 10.3189/ $172756501781832593)$

Xiao C and 10 others (2007) Observed changes of cryosphere in China over the second half of the 20th century: an overview. Ann. Glaciol., 46, 382-390 (doi: 10.3189/ 172756407782871396)

Yamazaki T (2001) A one-dimensional land surface model adaptable to intensely cold regions and its applications in Siberia. J. Meteorol. Soc. Jpn, 79(6), 1107-1118

Yamazaki T, Kondo J, Sakuraoka T and Nakamura T (1993) A onedimensional model of the evolution of snow-cover characteristics. Ann. Glaciol., 18, 22-26

Yang W and 6 others (2011) Summertime surface energy budget and ablation modeling in the ablation zone of a maritime Tibetan glacier. J. Geophys. Res., 116(D14), D14116 (doi: 10.1029/2010JD015183)

Yao T, Liu S, Pu J, Shen Y and Lu A (2004) Glacier retreat in high Asia and its impact on water resource of Northwest China. Sci. China D, 34(6), 535-543 [in Chinese]

Yatagai A and Yasunari T (1998) Variation of summer water vapor transport related to precipitation over and around the arid region in the interior of the Eurasian continent. J. Meteorol. Soc. Jpn, 76(5), 799-815

Ye Q, Kang S, Chen F and Wang J (2006) Monitoring glacier variations on Geladandong mountain, central Tibetan Plateau, from 1969 to 2002 using remote-sensing and GIS technologies. J. Glaciol., 52(179), 537-545 (doi: 10.3189/ 172756506781828359)

You Q, Kang S, Li C, Li M and Liu J (2007) Variation features of meteorological parameters at the Nam Co Station, Tibetan Plateau. Meteorol. Monthly, 33(3), 54-60 [in Chinese with English summary]

Zhang Y, Yao T, Pu J, Ohata T, Yabuki H and Fujita K (1996) Energy budget at ELA on Dongkemadi glacier in the Tonggula Mts, Tibetan Plateau. J. Glaciol. Geocryol., 18(1), 10-19 [in Chinese with English summary]

Zhou S, Kang S, Gao T and Zhang G (2010) Response of Zhadang glacier runoff in Nam Co Basin, Tibet, to changes in air temperature and precipitation form. Chinese Sci. Bull., 55(20), $2103-2110$ 